\title{
Production, reproduction, health, and growth traits in backcross Holstein $\times$ Jersey cows and their Holstein contemporaries ${ }^{1}$
}

\author{
D. W. Bjelland, ${ }^{\star 2}$ K. A. Weigel, ${ }^{\star}$ P. C. Hoffman, ${ }^{\star}$ N. M. Esser, ${ }^{\star}$ W. K. Coblentz, $†$ and T. J. Halbach‡ \\ *Department of Dairy Science, University of Wisconsin, Madison 53706 \\ †US Dairy Forage Research Center, Marshfield, WI 54449 \\ †Holstein Association USA, Battleboro, VT 05302
}

\section{ABSTRACT}

A total of 648 purebred Holstein and 319 backcross Holstein $\times$ Jersey dairy cattle were compared for production, reproduction, health, linear type, and growth traits. Animals were born between 2003 and 2009 and were housed in the University of Wisconsin-Madison Integrated Dairy Facility. All animals had Holstein dams; lactating dams were mated to unproven Holstein sires to produce purebred (control) Holsteins or to unproven $\mathrm{F}_{1}$ Jersey $\times$ Holstein crossbred sires to produce backcross animals, whereas nulliparous dams were mated to proven Holstein sires to produce purebred (other) Holsteins. Traits were analyzed using mixed linear models with effects of season of birth, age of dam, sire, birth year of sire, days in milk, lactation, and linear type score evaluator. Control Holsteins had greater 305 -d milk yield $(12,645$ vs. $11,456 \mathrm{~kg}), 305$-d mature equivalent milk yield $(13,420$ vs. $12,180 \mathrm{~kg})$, peak daily milk yield ( 49.5 vs. $46.4 \mathrm{~kg}$ ), total lactation milk yield $(11,556$ vs. $10,796 \mathrm{~kg})$, and daily fat-corrected milk yield (43 vs. $40 \mathrm{~kg}$ ) compared with backcrosses. Days open and services per conception as a heifer or cow did not differ between control Holsteins, other Holsteins, or backcrosses. The proportion of first-parity births that required assistance was less in control Holsteins than in backcross cows (3.7 vs. 11.2\%). The incidence of scours or respiratory problems in calves did not differ between control Holsteins, other Holsteins, and backcrosses, nor did the incidence of mastitis, injury, or feet problems. Control Holstein heifers were heavier (629 vs. $557 \mathrm{~kg}$ ), with greater hip height (145 vs. $139 \mathrm{~cm}$ ), body length $(167$ vs. $163 \mathrm{~cm})$, heart girth (205 vs. $198 \mathrm{~cm})$, and hip width (54 vs. $53 \mathrm{~cm}$ ) at 22 mo of age. On a 50-point scale for linear type traits, Holsteins were larger in stature compared with backcrosses (41 vs. 28), had wider

\footnotetext{
Received February 23, 2011.

Accepted June 7, 2011.

${ }^{1}$ Mention of trade names or commercial products in this article is solely for the purpose of providing specific information and does not imply either recommendation or endorsement by the US Department of Agriculture.

${ }^{2}$ Corresponding author: dbjelland@wisc.edu
}

rumps (37 vs. 33), and wider rear udders (34 vs. 32). Results of this study suggest that backcross Holstein $\times$ Jersey cattle have decreased production but fail to demonstrate an advantage in health and reproduction compared with purebred Holsteins.

Key words: crossbreeding, backcross, Jersey

\section{INTRODUCTION}

Over the past several decades, the average milk production per cow has greatly increased. Although nutrition and management have helped to improve production, genetic selection has accounted for more than $55 \%$ of the phenotypic gains in yield traits (Shook, 2006). In contrast to improved milk production, health and fertility traits have decreased. From 1976 to 1999, rolling herd averages for milk yield increased from 4,753 to $6,375 \mathrm{~kg}$ for southeastern Holsteins. During this period, days open increased from 124 to $168 \mathrm{~d}$, and services per conception increased from 1.91 to 3.00 (Washburn et al., 2002). Throughout this time period, the majority of commercial dairy farms relied on the high-producing Holsteins, with only $5 \%$ of US dairy cattle being breeds other than purebred Holstein (McAllister, 2002). Crossbreeding Holsteins with other breeds has been considered as an option to help minimize the decline of health and fertility, by introducing favorable genes, removing inbreeding depression, and taking advantage of heterosis.

Interest in crossbreeding has grown over the past decade among both dairy producers and researchers (Weigel and Barlass, 2003; Heins et al., 2006c). Many recent studies have compared Holsteins with $\mathrm{F}_{1}$ crosses involving Jerseys (Heins et al., 2008b; Olson et al., 2009), Brown Swiss (Dechow et al., 2007), and European breeds such as Normande, Montbéliarde, and Scandinavian Red (Heins et al., 2006c). Among these breeds, Jerseys were initially thought to best complement the Holstein breed due to their advantage in milk composition and fertility. Other characteristics of the Jersey breed, such as strong within-breed selection, competitive milk yield per unit of BW, and demonstrated heterosis with Holsteins, have led to their 
inclusion in crossbreeding programs (McAllister, 2002). Previous studies involving $\mathrm{F}_{1}$ Holstein $\times$ Jersey crossbreds have examined many economically important traits. Heins et al. (2008a) indicated a decrease in milk production and protein yield of crossbreds compared with Holsteins, but no difference was observed in fat yield. This study also noted that days open for first lactation crossbreds was lower than that of Holsteins. Olson et al. (2009) reported a significant decrease in dystocia for Jersey-sired crossbred calves compared to Holstein calves. VanRaden and Sanders (2003) reported that $\mathrm{F}_{1}$ Holstein $\times$ Jersey crossbreds were more profitable than pure Holsteins when strong premiums were placed on fat and protein percentages. A study of the use of Holstein-Friesian, Jersey, and Ayrshire breeds in crossbreeding mating systems in New Zealand also resulted in all crossbreds being more profitable than purebreds (Lopez-Villalobos, et al., 2000).

To understand if a 2-breed rotational crossbreeding system involving the Holstein and Jersey breeds would be suitable, an evaluation of advanced generations of the breeding program was undertaken. The backcross animals in this study were 3/4 Holstein:1/4 Jersey, which would represent a second generation in a 2-breed rotational cross. In the long-term, a commercial 2 breed rotational cross would lead to animals that are about $2 / 3$ one breed and $1 / 3$ the other, in any given generation. Some theory regarding the performance of backcross animals had been reported by Rutledge (2001). The initial $F_{1}$ crossbreds are formed from gametes with no possible between-genome recombination. But when gametes are formed in the $\mathrm{F}_{1}$ animals, recombination occurs between the chromosomes of the 2 parental breeds. This results in a breakup of ancestral coadapted gene complexes. Furthermore, backcross animals will exhibit only half of the heterosis found in $\mathrm{F}_{1}$ animals, due to $75 \%$ of the DNA coming from just 1 of the parental breeds, instead of half from each parental breed. The combination of these 2 events theoretically results in a loss of performance of backcross animals compared with the $\mathrm{F}_{1}$ animals.

\section{MATERIALS AND METHODS}

\section{Data Collection}

A total of 648 purebred Holstein and 319 backcross Holstein $\times$ Jersey heifers were born at the University of Wisconsin-Madison Integrated Dairy Facility (Arlington, Madison, and Marshfield, WI) between November 2003 and July 2009. The backcross animals were produced by randomly mating lactating Holstein cows to 1 of 7 unproven $F_{1}$ Holstein $\times$ Jersey sires from ABS Global (DeForest, WI), Alta Genetics Inc. (Watertown,
WI), and Select Sires Inc. (Plain City, OH). Of the crossbred sires, 4 were sired by Holsteins, whereas 3 were sired by Jerseys. Information regarding the identity and parentage of these sires are presented by Maltecca et al. (2006). These matings resulted in the $3 / 4$ Holstein:1/4 Jersey animals used in this study, which will be referred to as backcrosses throughout the remainder of this paper. The remaining lactating Holstein cows were randomly mated to unproven Holstein sires from commercial AI studs; the animals produced from these matings represented the experimental controls in this study and are referred to as control Holsteins. Nulliparous Holstein heifers were mated to proven Holstein sires; these matings were not randomized and resulted in a separate group of Holsteins, which are referred to as other Holsteins throughout this paper.

The weighted average sire genetic merit for each group is provided in Table 1. Genetic information was only available for 5 of the $7 \mathrm{~F}_{1}$ crossbred sires used in this study. Genetic merit for all groups are presented on a Holstein base. As expected, both Holstein groups exceeded the crossbred sires in milk production, although fat and protein production were similar. The crossbred sire's genetic merit for daughter pregnancy rate exceeded those of the Holsteins, but cow and heifer conception rate did not vary greatly. Overall, the other (proven) Holsteins exceeded both the control (young) Holsteins and crossbreds for net merit (\$190 vs. $\$ 17$ and $\$ 77$, respectively), fluid merit ( $\$ 169$ vs. $-\$ 12$ and $-\$ 23$, respectively), and cheese merit ( $\$ 218$ vs. $-\$ 7$ and $\$ 180$, respectively). Crossbred sires did have a greater genetic merit than control sires for net merit and cheese merit, but means for fluid merit were very similar.

External skeletal measurements: body length (point of the shoulders to the ischium), heart girth, and hip height, along with BW and BCS were taken on heifers at 60-d intervals from 4 to 22 mo of age, and $60-\mathrm{d}$ prepartum measurements were also recorded. Prepar-

Table 1. Weighted average sire genetic merit of Holstein and backcross Holstein $\times$ Jersey cows $^{1}$

\begin{tabular}{lccc}
\hline Item & $\begin{array}{c}\text { Control } \\
\text { Holstein }\end{array}$ & $\begin{array}{c}\text { Other } \\
\text { Holstein }\end{array}$ & Backcross \\
\hline Milk, kg & 94 & 222 & -345 \\
Fat, kg & 3 & 10 & 9 \\
Protein, kg & 4 & 10 & 1 \\
Productive life, mo & -0.8 & 0.7 & 0.8 \\
SCS & 3.04 & 3.00 & 3.22 \\
Daughter pregnancy rate, $\%$ & -0.7 & -2.8 & 2.0 \\
Cow conception rate, $\%$ & -0.9 & 0.0 & -0.8 \\
Heifer conception rate, $\%$ & 0.3 & 0.4 & 0.0 \\
Net merit, $\$$ & -16 & 190 & 77 \\
Fluid merit, $\$$ & -23 & 169 & -12 \\
Cheese merit, $\$$ & -7 & 218 & 180 \\
\hline
\end{tabular}

${ }^{1}$ Control $(\mathrm{n}=41)$; other $(\mathrm{n}=28)$; backcross $(\mathrm{n}=5)$. 
tum measurements included BW and BCS, as well as hip height, hip width, body length, heart girth, cannon bone circumference, pelvic height, pelvic width, pelvic area, and pelvic length. Pelvic height, width, and calculated pelvic area were determined using a calibrated pelvic forceps (HCR, Wright City, MO). All body measurement data were recorded at the University of Wisconsin-Madison Integrated Dairy Facility (Marshfield, WI). Due to the small number of other Holsteins in some age groups, the control and other Holstein groups were combined for statistical analysis in the measurements taken at 60 -d intervals.

First-, second-, and third-lactation health, reproductive, and production data, as well as health and reproductive data of nulliparous heifers, were obtained from Dairy Comp 305 files (Valley Ag. Software, Tulare, $\mathrm{CA})$. Health traits included the incidence of scours, defined as the percentage of calves that scoured the first $35 \mathrm{~d}$ of life; the incidence of respiratory disorders, defined as the percentage of calves that had respiratory problems in the first $200 \mathrm{~d}$ of life; and the incidence of mastitis, feet problems, and injury, defined as the percentage of animals with a given disorder during the corresponding lactation. Survival, which was defined as the percentage of animals culled before 24, 36, and 42 mo of age, was also analyzed. All animals that were still in the herd were required to pass the $24-, 36-$, or 42-mo thresholds to be included in the culling analysis, to allow each animal the opportunity to be culled.

Reproductive traits evaluated in this study were services per conception as a nulliparous heifer and lactating cow, age at first calving, birth weight of calf, gestation length, calving ease, DIM at first breeding, days open, and the percentage of animals pregnant by 100, 150, 200, and 250 DIM. Calving ease was recorded on a 5 -point ordinal scale. All calvings labeled as 1 or 2 were classified as 0 (no assistance) and calvings labeled as 3 , 4, or 5 were classified as 1 (assistance required). Calving ease data were expressed as the percentage of each breed group that required calving assistance. Only calving ease scores corresponding to first calvings were used, as very few animals had calving difficulty in later lactations. In the analysis of days open, cows were required to be at least $250 \mathrm{~d}$ postpartum if they had not been confirmed pregnant. All cows with greater than $250 \mathrm{~d}$ open were set to $250 \mathrm{~d}$, which followed the process performed by VanRaden et al. (2004). Cows designated as do not breed before reaching $250 \mathrm{~d}$ postpartum, regardless of reason, were removed from the reproductive analysis. When analyzing the percentage of cows pregnant at a given DIM, each nonpregnant cow was required to be at least $100,150,200$, or $250 \mathrm{~d}$ postpartum to be included in each analysis, to give the cow an opportunity to become pregnant.
Production traits included 305-d milk yield, 305-d mature equivalent milk yield, peak milk yield, total milk yield, total fat yield, total protein yield, FCM yield, log SCC, MUN, and milking speed. Cows were required to be at least 100 DIM to be included in the analyses for production traits. Fat-corrected milk, log SCC, MUN, and milking speed were defined as the average of all measurements throughout the lactation.

Linear type scores were recorded in first and second lactation. These included stature, strength, body depth, dairy form, rump angle, rump width, rear legs side view, rear legs rear view, foot angle, fore udder attachment, rear udder height, rear udder width, udder cleft, udder depth, front teat placement, teat length, and udder tilt. Evaluations were recorded on a 50-point scale by trained evaluators. Due to the small number of other Holsteins that were evaluated for linear type scores, the control and other Holsteins were combined for this analysis.

\section{Statistical Analysis}

All statistical analyses were performed using version 2.72 of $\mathrm{R}$ ( $\mathrm{R}$ foundation for Statistical Computing, 2008). Body measurements of nulliparous heifers were analyzed using linear mixed models. Separate analyses were carried out for measurements at each of nine 60-d intervals from 170 to $650 \mathrm{~d}$ of age. Fixed explanatory variables of birth season, age of dam, sire birth year, and age deviation from the mean of the group, as well as random variables of pen number and sire, were considered for each model. Backward deletion Akaike information Criterion (AIC) was performed, starting with these full models, to find suitable models to calculate least squares means and significance tests. For almost all traits, birth year-season and age deviation were significant and were included in the final model. Sire birth year and the age of dam were also included in some models, whereas the random effects of pen number and sire were significant in only 3 and 2 models, respectively.

The incidence of scours, respiratory problems, and calving difficulty were analyzed using logistic regression, whereas services per conception as a nulliparous heifer were analyzed using Poisson regression. The age at first calving, as well as 60-d prepartum (about $22 \mathrm{mo}$ of age) body measurements for BW, BCS, hip height, hip width, body length, heart girth, cannon bone circumference, pelvic height, pelvic width, pelvic area, and pelvic length, were analyzed with linear mixed models. The nuisance explanatory variables of year-season of birth, age of dam, and sire birth year, and the random sire effect were considered for each model. Again, backward deletion AIC was performed to find an adequate 
model for each trait. All health traits discussed, including the incidence of clinical mastitis, feet problems and injury, and the percentage culled before 24,32 , and 42 mo of age were analyzed using logistic regression. Nuisance explanatory variables of year-season of birth, age of dam, and sire birth year, and a random sire effect were considered for all traits, whereas a fixed effect of lactation number and a random animal effect were also considered for the incidence of mastitis and feet problems. Only first-lactation data were used when analyzing the incidence of injury, due to very few animals being injured in second or third lactation. Backward deletion AIC was performed to acquire a suitable model for each trait.

Reproductive data, including gestation length, DIM at first breeding, days open, and birth weight of the calf were analyzed using a linear mixed model. Services per conception was analyzed using Poisson regression, whereas the percentage pregnant at 100,150, 200, and $250 \mathrm{~d}$ postpartum were analyzed using logistic regression. Each reproductive trait analysis used records from first, second, and third lactations. The nuisance explanatory variables considered for these traits included year-season of birth, age of dam, sire birth year, lactation number, a random animal effect, and a random sire effect. Again, backward deletion AIC was performed for each trait to find a suitable model.

All of the production traits were analyzed using linear mixed models. These traits included observations from first, second, and third lactations. Each analysis considered year-season of birth, age of dam, sire birth year, DIM at time of data collection, lactation number, a random animal effect, and a random sire effect as nuisance explanatory variables. Backward deletion AIC was performed to find a suitable model for each trait.

Linear type traits were analyzed using linear mixed models. Observations were recorded during first and second lactation. When analyzing linear type traits, the following nuisance explanatory variables were considered: birth year-season, age of dam, sire birth year, evaluator, DIM at time of evaluation, lactation number, a random animal effect, and a random sire effect. Backward deletion AIC was performed for each trait to find a suitable model.

Supplementary Tables 1-5 (available online at http://journalofdairyscience.org) provide information on which nuisance explanatory variables are used for each trait mentioned previously.

\section{RESULTS AND DISCUSSION}

\section{Heifer Health and Reproductive Traits}

Least squares means for heifer health and reproductive traits are presented in Table 2. There were no significant differences between control Holsteins, other Holsteins, and backcrosses in the occurrence of scours or respiratory disorders. All cows were bred back to Holstein sires, and services per conception and age at first calving were similar between breed groups, but control Holsteins showed a much lower incidence of first calvings requiring assistance ( $\geq 3$ on a 5 -point scale) than did backcrosses (3.7 vs. $11.2 \%$ ).

Throughout the heifer-rearing period, no evidence was found that the backcross heifers exhibited any improvement in health or reproductive efficiency, although an increase among backcrosses requiring assistance during first calving was discovered. Calving problems can have detrimental effects on subsequent lactation and reproductive performance (Dematawewa and Berger, 1997). Previously Heins et al. (2006a) had noted a substantial decrease in calving difficulties among crossbred dams of several breed mixes as compared with Holsteins (3.7 to 11.6 vs. $17.7 \%$ ). A more recent study by Heins et al. (2010) analyzed the differences in calving difficulty from $\mathrm{F}_{1}$ Holstein $\times$ Jersey cows and Holstein cows bred to either Holstein or Montbéliarde sires. Breed combinations did not differ in calving difficulty.

\section{Heifer Growth and Body Size}

Results of 22-mo body measurements are also presented in Table 2, and these indicate that control Holsteins and other Holsteins were larger than the backcross heifers for each trait. These included BW (629 vs. $557 \mathrm{~kg}$ ), hip height (145 vs. $139 \mathrm{~cm})$, hip width $(54.4$ vs. $52.6 \mathrm{~cm}$ ), body length (167 vs. $163 \mathrm{~cm})$, heart girth $(205$ vs. $198 \mathrm{~cm})$, cannon bone circumference (28.16 vs. $27.15 \mathrm{~cm})$, pelvic height (18.73 vs. $18.37 \mathrm{~cm})$, pelvic width (16.61 vs. $16.23 \mathrm{~cm}$ ), pelvic area (225 vs. 215 $\mathrm{cm}^{2}$ ), and pelvic length (56.60 vs. $54.72 \mathrm{~cm}$ ), for control Holstein and backcross heifers, respectively. Body condition score was also measured at this age, but no difference was observed when comparing either group of Holsteins with backcrosses.

Body measurements for BW, hip height, body length, heart girth, and BCS were also taken at 60-d intervals from 4 to 22 mo of age. Results are shown in Figures $1-5$. Holsteins (pooled across groups) were significantly larger than backcrosses for BW, hip height, body length, and heart girth at every age measured. No differences were observed in BCS between Holsteins and backcrosses at any age.

Results presented herein are similar to those of previous studies involving body size of Holstein $\times$ Jersey crossbreds and purebred Holsteins. Heins et al. (2008a) noted that $F_{1}$ Holstein $\times$ Jersey crossbred cows were lighter (467 vs. $500 \mathrm{~kg}$ ) in the first $150 \mathrm{~d}$ of first lactation than purebred Holsteins. Furthermore, Anderson 
Table 2. Least squares means of reproductive, health, and 22-mo body size data of Holstein and backcross Holstein $\times$ Jersey heifers

\begin{tabular}{|c|c|c|c|c|c|c|}
\hline Item & \multicolumn{2}{|c|}{ Control Holstein } & \multicolumn{2}{|c|}{ Other Holstein } & \multicolumn{2}{|c|}{ Backcross } \\
\hline Scours $^{1,2}$ & 37.5 & 4.4 & 32.9 & 2.0 & 45.0 & 2.6 \\
\hline Services per conception ${ }^{4}$ & 1.49 & 0.09 & 1.49 & 0.05 & 1.49 & 0.05 \\
\hline Calving ease as dam ${ }^{4,5}$ & $3.7^{\mathrm{a}}$ & 2.4 & $5.0^{\mathrm{ab}}$ & 1.5 & $11.2^{\mathrm{b}}$ & 1.9 \\
\hline Age at first calving, ${ }^{4} \mathrm{~d}$ & 730 & 4.31 & 729 & 2.44 & 721 & 2.53 \\
\hline Hip height ${ }^{6}{ }^{\mathrm{cm}}$ & $145^{\mathrm{a}}$ & 0.43 & $144^{\mathrm{a}}$ & 0.33 & $139^{\mathrm{b}}$ & 0.26 \\
\hline Hip width, ${ }^{6} \mathrm{~cm}$ & $54.4^{\mathrm{a}}$ & 0.29 & $54.9^{\mathrm{a}}$ & 0.22 & $52.6^{\mathrm{b}}$ & 0.17 \\
\hline Body length, ${ }^{6} \mathrm{~cm}$ & $167^{\mathrm{a}}$ & 0.70 & $168^{\mathrm{a}}$ & 0.57 & $163^{\mathrm{b}}$ & 0.44 \\
\hline Heart girth, ${ }^{6} \mathrm{~cm}$ & $205^{\mathrm{a}}$ & 0.78 & $204^{\mathrm{a}}$ & 0.50 & $198^{\mathrm{b}}$ & 0.53 \\
\hline Cannon bone circumference, ${ }^{6} \mathrm{~cm}$ & $28.16^{\mathrm{a}}$ & 0.13 & $28.33^{\mathrm{a}}$ & 0.09 & $27.15^{\mathrm{b}}$ & 0.07 \\
\hline Pelvic height, ${ }^{6} \mathrm{~cm}$ & $18.73^{\mathrm{a}}$ & 0.15 & $18.84^{\mathrm{a}}$ & 0.11 & $18.37^{\mathrm{b}}$ & 0.09 \\
\hline Pelvic width,${ }^{6} \mathrm{~cm}$ & $16.61^{\mathrm{a}}$ & 0.15 & $16.94^{\mathrm{b}}$ & 0.09 & $16.23^{\mathrm{c}}$ & 0.08 \\
\hline
\end{tabular}

\footnotetext{
${ }^{a-c}$ Least squares means with different superscripts within rows are significantly different $(P<0.05)$.

${ }^{1}$ Control $(\mathrm{n}=111)$; other $(\mathrm{n}=537)$; backcross $(\mathrm{n}=319)$.

${ }^{2}$ Scours defined as percentage of group to have scours in first $35 \mathrm{~d}$.

${ }^{3}$ Respiratory disorder defined as percentage of group to have respiratory problems in first $200 \mathrm{~d}$.

${ }^{4}$ Control $(\mathrm{n}=84)$; other $(\mathrm{n}=249)$; backcross $(\mathrm{n}=271)$.

${ }^{5}$ Percentage of births requiring assistance $(\geq 3)$.

${ }^{6}$ Control $(\mathrm{n}=65)$; other $(\mathrm{n}=107)$; backcross $(\mathrm{n}=174)$; measured at 22 mo of age.
}

et al. (2007) noted that Holstein $\times$ Jersey crossbred cows were, on average, $93 \mathrm{~kg}$ lighter than purebred Holsteins. In a study of Holstein $\times$ Guernsey crossbreds, Touchberry (1992) concluded that Holstein $\times$ Guernsey crossbreds were smaller than purebred Holsteins, and that these crossbreds exceeded the parental means due to a heterosis effect of about $5.0 \%$ for BW. This difference in body size had also been noted by producers in a survey conducted by Weigel and Barlass (2003) and was considered as one of the main challenges that these producers faced with their crossbreeding program.

\section{Reproductive Traits}

Least squares means of calf $\mathrm{BW}$ and reproductive traits are provided in Table 3. Calves born from Holstein bulls mated to control Holsteins $(43.0 \mathrm{~kg})$ and other Holsteins $(44.2 \mathrm{~kg})$ were significantly heavier than calves from backcross dams $(40.5 \mathrm{~kg})$. Gestation length, services per conception, days open, and DIM at first breeding did not differ between control Holsteins, other Holsteins, and backcrosses. The similarity in days to first breeding is most likely attributed to the extensive use of synchronization protocols in this herd, which may also limit possible differences between breeds for other reproductive traits. These results also suggest excellent overall reproductive performance. Reproductive efficiency was further analyzed by calculating the percentage of animals pregnant by 100, 150, 200, and
250 d postpartum. More control Holsteins (66.0\%) were pregnant by 100 DIM as compared with other Holsteins

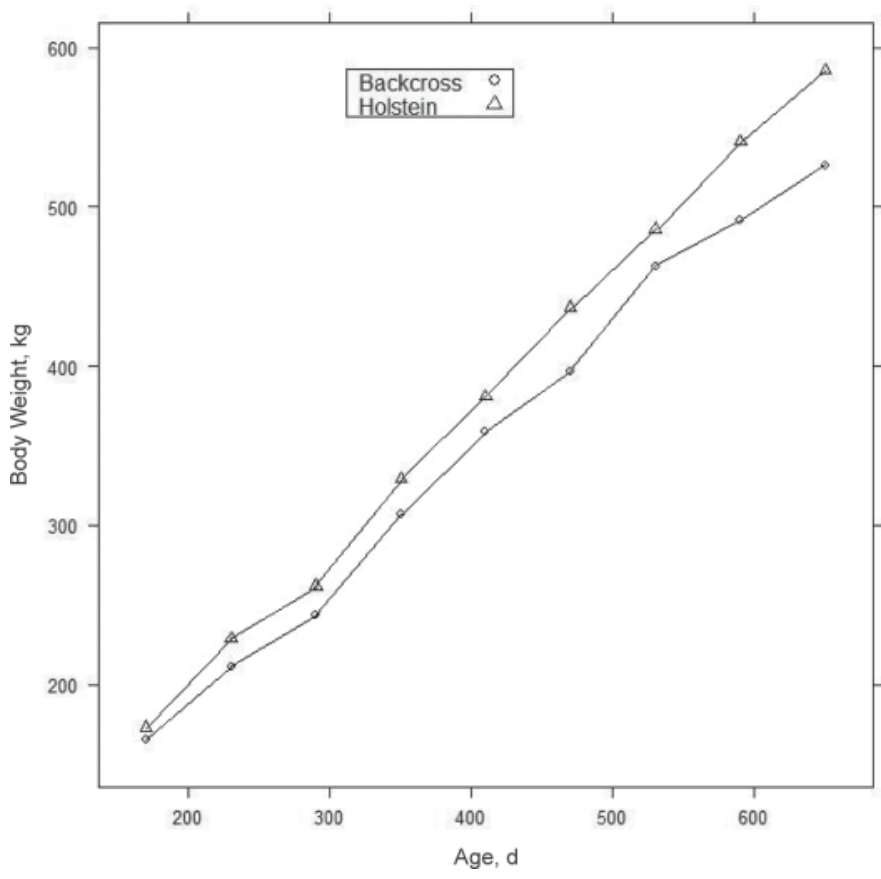

Figure 1. Body weight of Holstein and backcross Holstein $\times$ Jersey heifers at 60-d intervals from 170 to $650 \mathrm{~d}$ of age. 


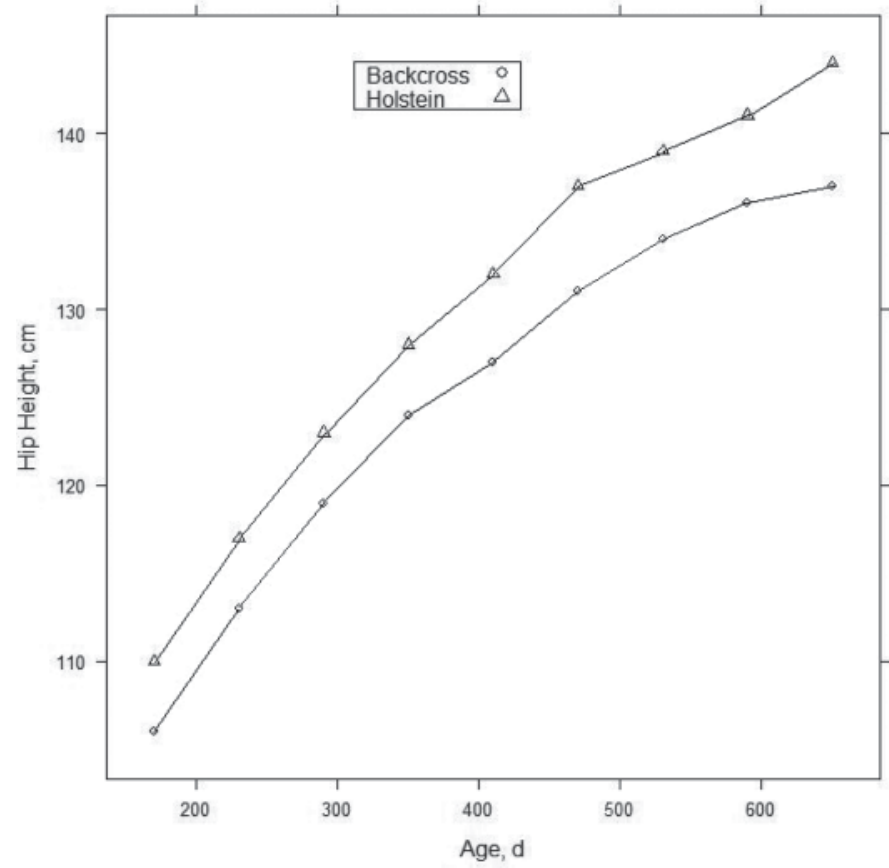

Figure 2. Hip height of Holstein and backcross Holstein $\times$ Jersey heifers at 60-d intervals from 170 to $650 \mathrm{~d}$ of age.

(45.0\%) and backcross cows (51.6\%), but no differences were observed at 150, 200, or $250 \mathrm{~d}$ postpartum.

These results suggest that the backcrosses in this study are not more reproductively efficient than Hol-

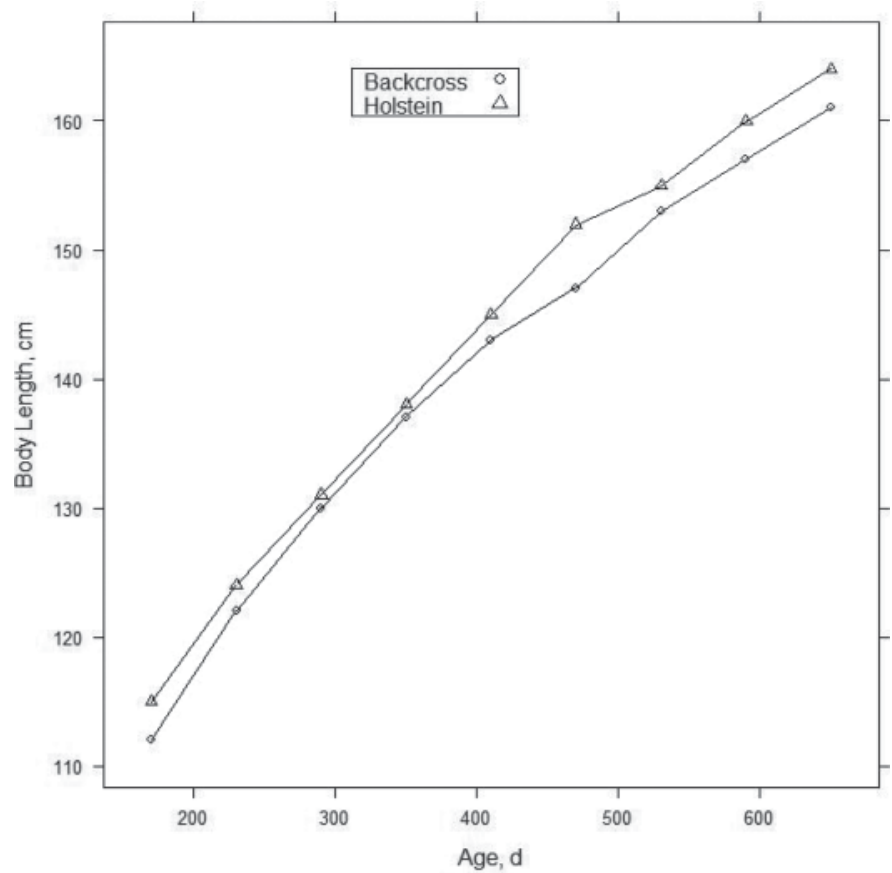

Figure 3. Body length of Holstein and backcross Holstein $\times$ Jersey heifers at 60 -d intervals from 170 to $650 \mathrm{~d}$ of age.

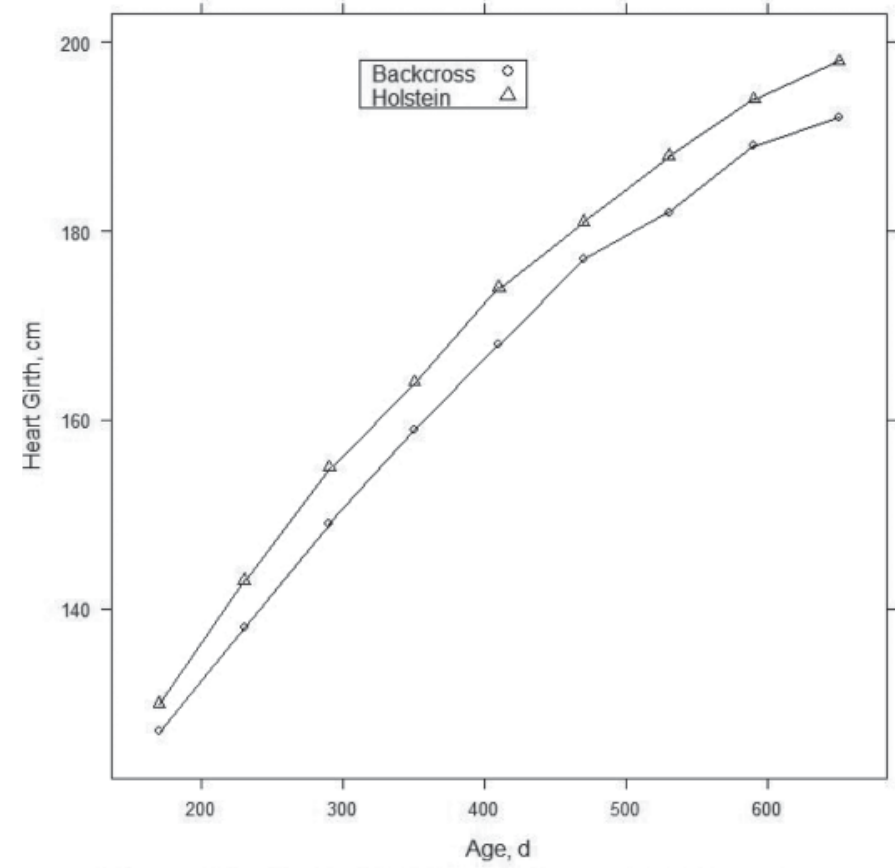

Figure 4. Heart girth of Holstein and backcross Holstein $\times$ Jersey heifers at 60 -d intervals from 170 to $650 \mathrm{~d}$ of age.

steins, at least in the management system used herein. Several previous studies had indicated an increase in reproductive performance of crossbred cows. Heins et al. (2008b) noted that $\mathrm{F}_{1}$ Holstein $\times$ Jersey cows had

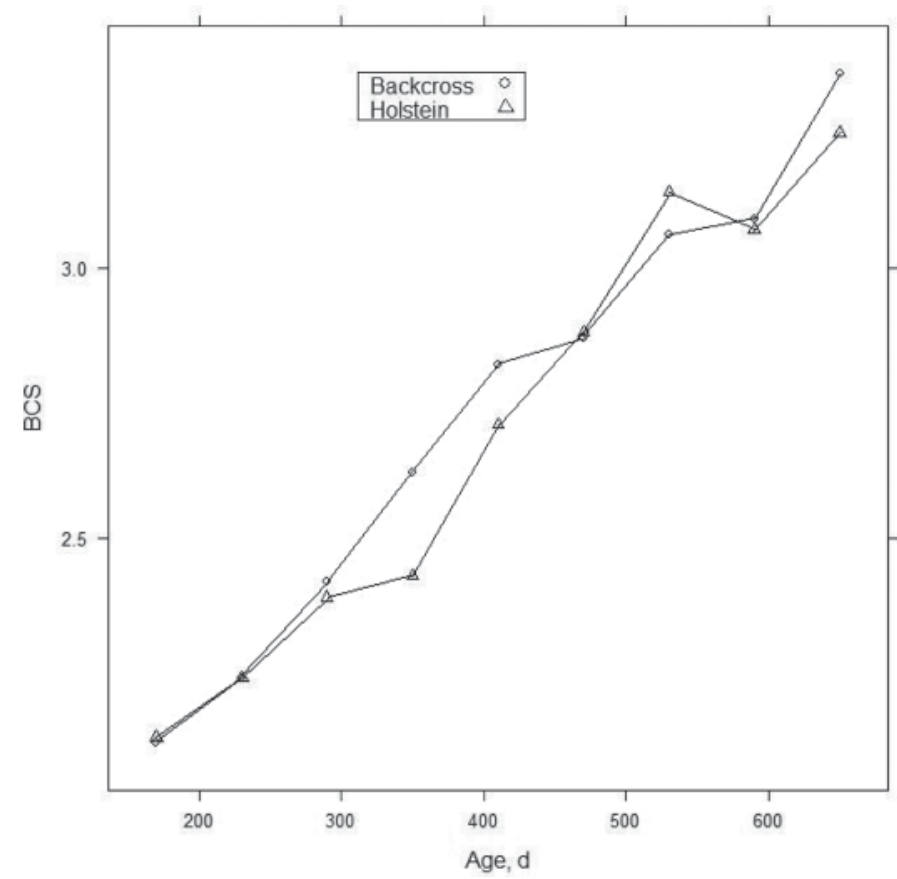

Figure 5. Body condition score of Holstein and backcross Holstein $\times$ Jersey heifers at 60 -d intervals from 170 to $650 \mathrm{~d}$ of age. 
Table 3. Least squares means of calf BW and reproductive data of Holstein and backcross Holstein $\times$ Jersey cows

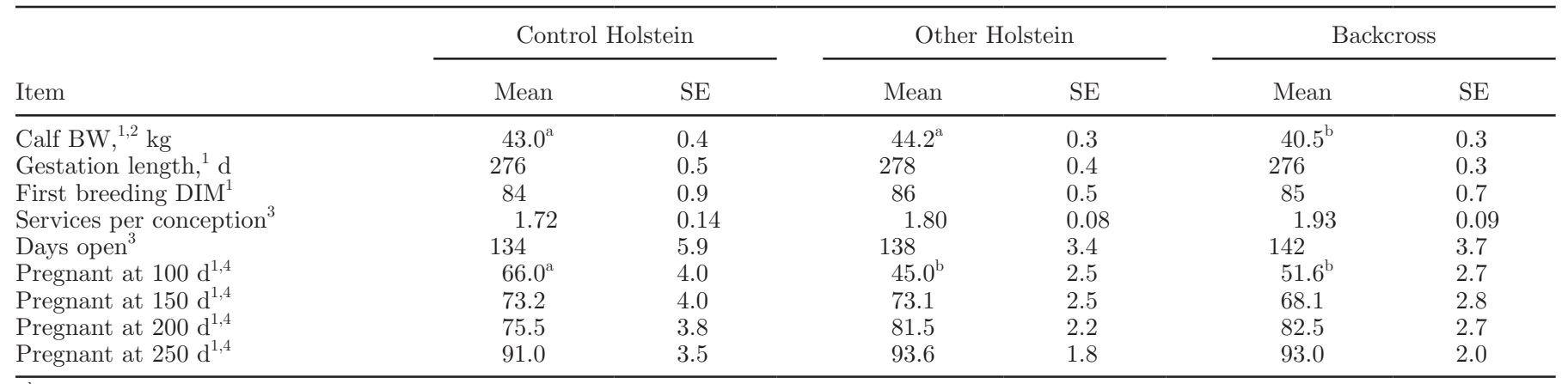

${ }^{a, b}$ Least squares means with different superscripts within rows are significantly different $(P<0.05)$.

${ }^{1}$ Control $(\mathrm{n}=152)$, other $(\mathrm{n}=360)$, backcross $(\mathrm{n}=348)$.

${ }^{2}$ Body weight of calves born from cows in this study.

${ }^{3}$ Control $(\mathrm{n}=140)$, other $(\mathrm{n}=299)$, backcross $(\mathrm{n}=351)$.

${ }^{4}$ Percentage of animals pregnant at corresponding DIM.

fewer days open (127 vs. 150 d) and a greater percentage of cows pregnant by $150 \mathrm{~d}$ postpartum (75 vs. $59 \%$ ) than purebred Holsteins. Dechow et al. (2007) reported that $\mathrm{F}_{1}$ Holstein $\times$ Brown Swiss crossbreds had fewer days open (144 vs. 156 d) than did Holsteins. However, Dechow et al. (2007) also showed that Brown Swiss $\times$ Holstein backcross cows did not differ from Holsteins for any reproductive trait considered. Advantages in reproduction for Holstein $\times$ Montbéliarde, Holstein $\times$ Normande, and Holstein $\times$ Scandinavian Red first-generation crosses over purebred Holsteins were presented by Heins et al. (2006b). As much previous data has shown, $F_{1}$ crosses have greater reproductive efficiency than Holsteins, but subsequent generations of crossbreds have not exhibited the same improvement. For a dairy crossbreeding program to be effective, the reproductive performance of all crossbred cows need to be better than that of purebred Holsteins to economically offset lesser milk production. Analysis of further crosses and further generations are required to completely assess the long-term differences between crossbreed and purebred cows.

\section{Health Traits}

Least squares means for health and survival traits are provided in Table 4. Control Holsteins, other Holsteins, and backcrosses did not differ in the percentage of cows that had clinical mastitis, feet problems, or other injuries, suggesting no overall improvement in health for the backcross cows. The percentages of cows culled before 24,36 , and 42 mo of age are also presented in Table 4. These included all cows that died or left the herd for various reasons, such as poor production, poor reproductive performance, or disease. The first 2 measurements, at 24 and 36 mo of age, did not differ between control Holsteins, other Holsteins, or backcrosses. However, a higher percentage of backcross cows (43.8\%) were culled by 42 mo of age, as compared with other Holsteins (33.7\%); no difference existed between either of these groups and control Holsteins (36.5\%).

As with reproductive traits, the backcross animals in this trial showed no overall improvement in the health traits analyzed in this study. First-lactation survival in crossbreds and Holsteins was previously presented by Heins et al. (2006b). First generation Normande $\times$ Holstein, Montbéliarde $\times$ Holstein, and Scandinavian Red $\times$ Holstein cows had greater survival to 30 (each 98 vs. 95\%), 150 (each 96 vs. 91\%), and 305 d postpartum $(93,92$, and 93 vs. $86 \%$ ) than purebred Holsteins. Crossbred cows in the study of Touchberry (1992) also had a higher percentage survive to first (85.1 vs. $79.0 \%$ ) and second calving (80.3 vs. $70.5 \%$ ) than purebred Holsteins. Previous research discussed herein has only considered results from first-generation crossbreds. Although the current study involves one of the next generation crosses, it is evident that more future generations of crossbred cows need to be studied to determine their true long-term advantage.

\section{Production Traits}

Least squares means for production traits are shown in Table 5. Control Holsteins and other Holsteins had greater production than backcross cows for 305-d milk yield $(12,645$ and 12,519 vs. $11,456 \mathrm{~kg}), 305$-d mature equivalent milk yield (13,420 and 13,509 vs. $12,180 \mathrm{~kg})$, peak milk yield (49.5 and 50.6 vs. $46.4 \mathrm{~kg}$ ), and total milk yield (11,566 and 11,956 vs. 10,796 kg). Although total fat yield and total protein yield did not differ, daily FCM was greater for control Holsteins (42.9 kg) and other Holsteins $(41.5 \mathrm{~kg}$ ) than backcrosses (39.5 
Table 4. Least squares means of health and survival data of Holstein and backcross Holstein $\times$ Jersey cows

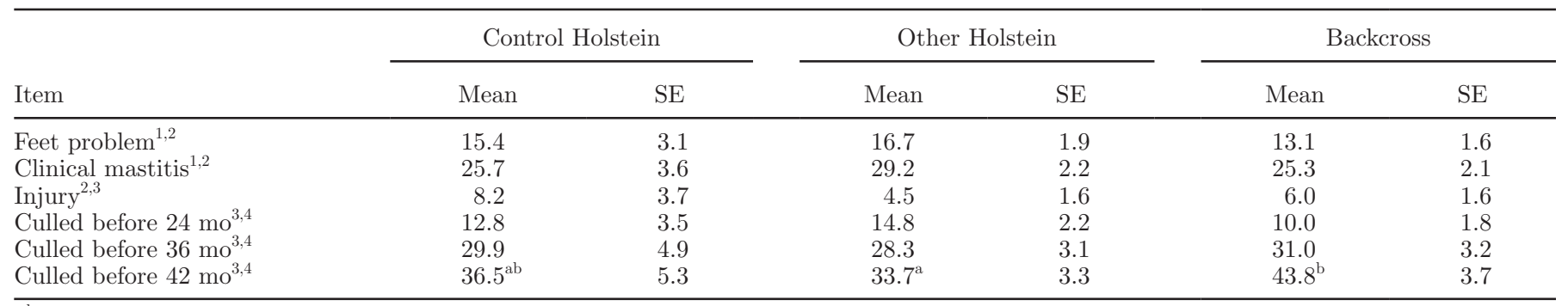

${ }^{\mathrm{a}, \mathrm{b}}$ Least squares means with different superscripts within rows are significantly different $(P<0.05)$.

${ }^{1}$ Control $(\mathrm{n}=176)$, other $(\mathrm{n}=440)$, backcross $(\mathrm{n}=426)$.

${ }^{2}$ Percentage of group that had disorder at least once during lactation.

${ }^{3}$ Control $(\mathrm{n}=87)$, other $(\mathrm{n}=228)$, backcross $(\mathrm{n}=216)$.

${ }^{4}$ Percentage of group culled before corresponding age.

$\mathrm{kg})$. Log SCC across the entire lactation was lower for control Holsteins (2.33) and other Holsteins (2.40) compared with backcrosses (2.81). No difference existed in MUN or milking speed between Holstein or backcross cows.

These results are similar to previous studies that involved $\mathrm{F}_{1}$ Holstein $\times$ Jersey crossbreds. Heins et al. (2008b) reported a decrease of $558 \mathrm{~kg}$ in $305-\mathrm{d}$ milk production between $\mathrm{F}_{1}$ Holstein $\times$ Jersey crossbreds and purebred Holsteins. Prendiville et al. (2010) reported a daily milk yield decrease of about $1 \mathrm{~kg} / \mathrm{d}$ for $\mathrm{F}_{1}$ crossbred versus Holstein cows under grazing conditions. Studies involving other breeds have also noted a decrease in total milk yield. Normande $\times$ Holstein, Montbéliarde $\times$ Holstein, and Scandinavian Red $\times$ Holstein cows each produced less milk, fat, and protein yield per lactation than purebred Holsteins (Heins et al., 2006c). The increased log SCC of backcross cows, as compared with Holsteins in the current study, is similar to results presented by Heins et al. (2008b), where the $\mathrm{F}_{1}$ crosses had a numerically higher SCC, although results were not statistically significant. Furthermore, analysis of feed intake and energy balance would be required to assess the profitability of crossbreeding. Olson et al. (2010) noted that Holsteins consumed more energy than $\mathrm{F}_{1}$ Holstein $\times$ Jersey crossbred cows, but both required more energy for production than purebred Jerseys. Further research to assess energy balance and feed efficiency would be beneficial to crossbreeding studies.

\section{Linear Type Scores}

Least squares means of linear type scores are presented in Table 6. Holsteins (pooled across groups) were larger in stature than the backcross cows (41.4 vs. 27.7 ), as well as having wider rumps (37.4 vs. 32.5 ), and shorter teats (18.5 vs. 22.2). Holsteins also exhibited less slope to the rump (27.2 vs. 29.1) and wider rear udders (33.9 vs. 31.7 ) when compared with backcrosses.

Heins et al. (2008b) reported an increase in BW, hip height, heart girth and thurl width of Holsteins compared with $\mathrm{F}_{1}$ Holstein $\times$ Jersey crosses in the first lactation. Heins et al. (2008b) also reported less ud-

Table 5. Least squares means of production data for Holstein and backcross Holstein $\times$ Jersey cows $^{1}$

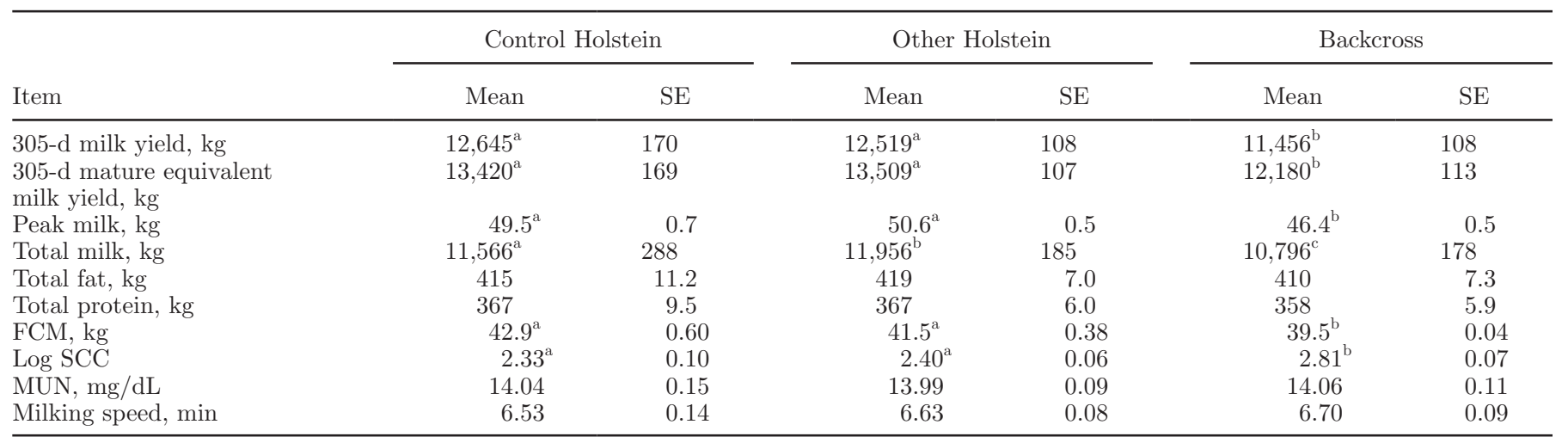

${ }^{\mathrm{a}-c}$ Least squares means with different superscripts within rows are significantly different $(P<0.05)$.

${ }^{1}$ Control $(\mathrm{n}=155)$; other $(\mathrm{n}=375)$; backcross $(\mathrm{n}=330)$. 
Table 6. Least squares means of linear type scores of Holstein and backcross Holstein $\times$ Jersey cows

\begin{tabular}{|c|c|c|c|c|}
\hline \multirow[b]{2}{*}{ Item } & \multicolumn{2}{|c|}{ Holstein $^{1}$} & \multicolumn{2}{|c|}{ Backcross $^{2}$} \\
\hline & Mean & SE & Mean & $\mathrm{SE}$ \\
\hline Stature & $41.4^{\mathrm{a}}$ & 0.8 & $27.7^{\mathrm{b}}$ & 0.7 \\
\hline Strength & 24.6 & 0.9 & 24.9 & 0.6 \\
\hline Body depth & 30.7 & 0.7 & 30.2 & 0.6 \\
\hline Dairy form & 28.4 & 0.8 & 29.2 & 0.6 \\
\hline Rump angle & $27.2^{\mathrm{a}}$ & 0.9 & $29.1^{\mathrm{b}}$ & 0.7 \\
\hline Rump width & $37.4^{\mathrm{a}}$ & 0.7 & $32.5^{\mathrm{b}}$ & 0.6 \\
\hline Rear legs side view & 23.6 & 0.7 & 24.0 & 0.6 \\
\hline Foot angle & 23.4 & 0.7 & 24.3 & 0.6 \\
\hline Fore udder attachment & 22.2 & 0.8 & 23.0 & 0.7 \\
\hline Rear udder height & 29.5 & 0.7 & 29.3 & 0.6 \\
\hline Rear udder width & $33.9^{\mathrm{a}}$ & 0.8 & $31.7^{\mathrm{b}}$ & 0.6 \\
\hline Udder cleft & 27.1 & 0.9 & 26.2 & 0.6 \\
\hline Udder depth & 23.9 & 0.8 & 20.8 & 0.6 \\
\hline Front teat placement & 24.5 & 0.8 & 25.2 & 0.6 \\
\hline Teat length & $18.5^{\mathrm{a}}$ & 0.6 & $22.2^{\mathrm{b}}$ & 0.5 \\
\hline Rear legs rear view & 22.2 & 0.7 & 21.8 & 0.7 \\
\hline Udder tilt & 22.5 & 0.7 & 22.5 & 0.6 \\
\hline
\end{tabular}

der clearance ( 47.7 vs. $54.6 \mathrm{~cm}$ ) and wider front teat placement $(15.8$ vs. $14.0 \mathrm{~cm})$ for these crossbreds than for Holsteins. These differences were not evident in the backcross cows in the present study, and several differences shown in the present study were not presented by Heins et al. (2008b). Inconsistencies may be due to differences in the Holstein and crossbred populations in these 2 experimental herds.

\section{CONCLUSIONS}

Based on the trial results, we conclude that backcross Holstein $\times$ Jersey cattle seen in this study do not perform as well as their purebred Holstein contemporaries. We observed no increase in reproductive efficiency, health, or longevity in these backcross cows, as compared with Holstein cows, and in some measures the Holsteins exhibited greater efficiencies. Milk production of these backcross cows, as compared with Holstein cows, was notably less. This combination of results does not suggest that this stage of a 2-breed rotational cross involving Holstein and Jersey breeds would provide a benefit over purebred Holsteins. The next several crosses, with animals approaching $2 / 3$ of one breed and $1 / 3$ of the other, would more closely emulate the long-term result of a commercial 2-breed crossbreeding program, but studies involving multiple generations are expensive and time and resource consuming. Based on results of this study, further research is needed to determine whether a continued long-term crossbreeding program would be more profitable and effective than a purebred system. Continuing this study by monitoring the production, health, and longevity of these cows in the fourth and fifth lactations will also give a better picture of overall lifetime performance of these cows.

\section{ACKNOWLEDGMENTS}

We acknowledge the help of the University of Wisconsin-Madison students, Linda Behling, Chrissy Wendorf, Carissa Levash, and Danielle Brown, as well as Brian Kelroy of the Holstein Association USA (Brattleboro, VT) in the collection of data. K. Weigel acknowledges financial support from the National Association of Animal Breeders (Columbia, MO). This project was supported by National Research Initiative Grant no 2004-14210 from the USDA Cooperative State Research, Education, and Extension Service, as well as a Hatch grant from the Wisconsin Agriculture Experiment Station.

\section{REFERENCES}

Anderson, T., R. Shaver, P. Bosma, and V. De Boer. 2007. Case study: Performance of lactation Jersey and Jersey-Holstein crossbred versus Holstein cows in a Wisconsin confinement dairy herd. Prof. Anim. Sci. 25:541-545.

Dechow, C. D., G. W. Rogers, J. B. Cooper, M. I. Phelps, and A. L. Mosholder. 2007. Milk, fat, protein, somatic cell score, and days open among Holstein, Brown Swiss, and their crosses. J. Dairy Sci. 90:3542-3549.

Dematawewa, C. M. B., and P. J. Berger. 1997. Effect of dystocia on yield, fertility, and cow losses and an economic evaluation of dystocia scores for Holsteins. J. Dairy Sci. 80:754-761.

Heins, B. J., L. B. Hansen, A. R. Hazel, A. J. Seykora, D. G. Johnson, and J. G. Linn. 2010. Birth traits of pure Holstein calves versus Montbeliarde-sired crossbred calves. J. Dairy Sci. 93:2293-2299. 
Heins, B. J., L. B. Hansen, and A. J. Seykora. 2006a. Calving difficulty and stillbirths of pure Holsteins versus crossbred of Holsteins with Normande, Montbeliarde, and Scandinavian Red. J. Dairy Sci. 89:2805-2810.

Heins, B. J., L. B. Hansen, and A. J. Seykora. 2006b. Fertility and survival of pure Holsteins versus crossbreds of Holstein with Normande, Montbeliarde, and Scandinavian Red. J. Dairy Sci. 89:4944-4951.

Heins, B. J., L. B. Hansen, and A. J. Seykora. 2006c. Production of pure Holsteins versus crossbreds of Holstein with Normande, Montbeliarde, and Scandinavian Red. J. Dairy Sci. 89:2799-2804.

Heins, B. J., L. B. Hansen, A. J. Seykora, A. R. Hazel, D. G. Johnson, and J. G. Linn. 2008a. Crossbreds of Jersey $\times$ Holstein compared with pure Holsteins for body weight, body condition score, dry matter intake, and feed efficiency during the first one hundred fifty days of first lactation. J. Dairy Sci. 91:3716-3722.

Heins, B. J., L. B. Hansen, A. J. Seykora, D. G. Johnson, J. G. Linn, J. E. Romano, and A. R. Hazel. 2008b. Crossbreds of Jersey $\times$ Holstein compared with pure Holsteins for production, fertility, and body and udder measurement during first lactation. J. Dairy Sci. 91:1270-1278.

Lopez-Villalobos, N., D. J. Garrick, C. W. Holmes, H. T. Blair, and R. J. Spelman. 2000. Profitabilities of some mating systems for dairy herds in New Zealand. J. Dairy Sci. 83:144-153.

Maltecca, C., H. Khatib, V. R. Schutzkus, P. C. Hoffman, and K. A. Weigel. 2006. Changes in conception rate, calving performance, and calf health and survival from the use of crossbred Jersey $x$ Holstein sires as mate for Holstein dams. J. Dairy Sci. 89:27472754 .

McAllister, A. J. 2002. Is crossbreeding the answer to questions of dairy breed utilization? J. Dairy Sci. 85:2352-2357.

Olson, K. M., B. G. Cassell, and M. D. Hanigan. 2010. Energy balance in first-lactation Holstein, Jersey, and reciprocal $\mathrm{F}_{1}$ cross- bred cows in a planned crossbreeding experiment. J. Dairy Sci. 93:4374-4385.

Olson, K. M., B. G. Cassell, A. J. McAllister, and S. P. Washburn. 2009. Dystocia, stillbirth, gestation length and birth weight in Holstein, Jersey, and reciprocal crosses from a planned experiment. J. Dairy Sci. 92:6167-6175.

Prendiville, R., K. M. Pierce, and F. Buckley. 2010. A comparison between Holstein-Friesian and Jersey dairy cows and their $\mathrm{F}_{1}$ cross with regard to milk yield, somatic cell score, mastitis, and milking characteristics under grazing conditions. J. Dairy Sci. 93:27412750 .

R Foundation for Statistical Computing. 2008. Version 2.72. http:// www.r-project.org.

Rutledge, J. J. 2001. Greek temples, tropical kine and recombination load. Livest. Prod. Sci. 68:171-179.

Shook, G. E. 2006. Major advances in determining appropriate selection goals. J. Dairy Sci. 89:1349-1361.

Touchberry, R. W. 1992. Crossbreeding effects in dairy cattle: The Illinois experiment, 1949 to 1969. J. Dairy Sci. 75:640-667.

VanRaden, P. M., and A. H. Sanders. 2003. Economic merit of crossbred and purebred US dairy cattle. J. Dairy Sci. 86:1036-1044.

VanRaden, P. M., A. H. Sanders, M. E. Tooker, R. H. Miller, H. D. Norman, M. T. Kuhn, and G. R. Wiggans. 2004. Development of a national genetic evaluation for cow fertility. J. Dairy Sci. $87: 2285-2292$.

Washburn, S. P., W. J. Silvia, C. H. Brown, B. T. McDaniel, and A. J. McAllister. 2002. Trends in reproductive performance in southeastern Holstein and Jersey DHI herds. J. Dairy Sci. 85:244-251.

Weigel, K. A., and K. A. Barlass. 2003. Results of a producer survey regarding crossbreeding on US dairy farms. J. Dairy Sci. $86: 4148-4154$ 